\title{
Safe before Green! The Greening of Volvo Cars in the 1970s-1990s
}

\author{
Ann-Kristin Bergquist (D) \\ Mattias Näsman
}

Although the automobile industry has served as the backbone of much business history scholarship, business historians have paid little attention to this industry's actions concerning the complex of environmental issues that took hold in the 1960s. Volvo represents a captivating case study to gain insight into why the automobile industry's growth has been difficult to align with the shift toward environmental sustainability. Although Volvo pioneered the exhaust emission control technology on the U.S. market in the 1970s and gained an international reputation for high environmental and safety standards in the decades that followed, the company was unable to seriously address climate change in the 1990s. This article identifies several key factors impacting the automobile industry's passive response to environmental challenges-for instance, weak and asymmetric emission control regulations on international markets, consumer preferences for larger cars (SUVs) in the 1990s, and a lack of systematic regulatory pressure to shift from fossil fuels and the internal combustion engine. In the case of Volvo, world leadership in safety standards, rather than low carbon emissions, constituted the company's competitive advantage as climate change emerged as one of the most critical environmental issues in the 1990s.

\section{Introduction}

Degradation of the natural environment, with the climate crisis as the broadest and most fundamental threat, today cuts across the global automobile industry. Although this industry's impact on the environment has been on the political agenda for at least half a century, transforming itself toward less environmentally damaging practices has proven extremely challenging. One of the most debated issues has been exhaust emissions from passenger cars. Whereas emissions of hydrocarbons (HC), carbon monoxide (CO), and nitrogen oxides $\left(\mathrm{NO}_{\mathrm{x}}\right)$ reached the political agenda in the 1960s, during the past three decades a growing concern regarding climate change has made carbon dioxide $\left(\mathrm{CO}_{2}\right)$ emissions an additional challenge

Published online June 21, 2021

(c) The Author(s), 2021. Published by Cambridge University Press on behalf of the Business History Conference. All rights reserved. This is an Open Access article, distributed under the terms of the Creative Commons Attribution licence (http://creativecommons.org/licenses/by/4.0/), which permits unrestricted re-use, distribution, and reproduction in any medium, provided the original work is properly cited. 
for automakers to address. ${ }^{1}$ Decades ago, numerous automakers declared that action on climate change was imperative; at the same time, however, few companies have lived up to their rhetoric. ${ }^{2}$ Increased discrepancy between "green" rhetoric and business practice has been identified as a general problem among large corporations since the 1980s and, according to some scholars, has presented a challenge almost as great as the neglect of environmental problems in the past. ${ }^{3}$

Although the automobile industry has indeed served as the backbone of much business history scholarship—not least in the seminal works of Alfred D. Chandler-little research in business history to date has examined how environmental regulations and the environmental debate at-large challenged the automobile industry to transform toward sustainability from the 1960s onward. ${ }^{4}$ As a result, there is a considerable gap in the literature offering insight into the historically shaped inertias and difficulties in transforming this industry with respect to the environment. ${ }^{5}$ As argued by Adam Rome in his recent study of the chemical company DuPont, there is an overall need for detailed historical studies of corporate environmental performance, as a multiauthored history of corporate responsibility in the United States has only touched on the subject. ${ }^{6}$ The same holds for virtually all other countries, including those in Europe. ${ }^{7}$

In this context, Volvo Cars Corporation (hereafter Volvo) represents a captivating case study. When U.S. car manufacturers fiercely fought against new environmental regulations in the 1970s, and the American public regarded the automobile as the environmental "public enemy number one," ${ }^{8}$ Volvo stood out as a proactive company. ${ }^{9}$ In 1972 , the company adopted "environmental care" as the third core value in its business operations, alongside "quality" and "safety." Volvo apparently embraced an emerging issue that, particularly, U.S. firms fought against. The person responsible for this early initiative was Volvo's chief executive officer since 1971, Pehr G. Gyllenhammar. His initiative was well-timed. The United Nations organized the first Conference on the Human Environment in Stockholm in 1972, ${ }^{10}$ and Sweden had already implemented a new environmental regulatory framework in 1969 and recently imposed new standards for exhaust emissions from automobiles. ${ }^{11}$ In the United States, which at the time had grown into Volvo's most important export market, the automobile industry had emerged as one of the most contested industries among environmentalists and the public. ${ }^{12}$ A historic turn

1. Geels et al., Automobility in Transition?; Unruh, "Understanding Carbon Lock-In" and "Escaping Carbon Lock-In"; Briggs, Webb, and Wilson, “Automotive Modal Lock-In.”

2. Cook, Automaker Rankings 2018.

3. Jones, Profits, 379.

4. Köhler has notably discussed German car firms' strategies of focusing on fuel-efficient cars as a result of the oil price shocks of the 1970s. See Köhler, “'Small Car Blues”” and “Overcoming Stagnation.” Wilkins briefly indicates how U.S. fuel efficiency standards invoked massive structural change in the U.S. industry during the same period. See Wilkins, "Multinational Automobile Enterprises and Regulation." See also Moguen-Toursel, "Strategies" and "Vers une co-production."

5. For recent literature overviews, see Bergquist, "Business and Sustainability," and Bergquist et al., "Roadblocks."

6. Rome, "DuPont," 76.

7. Bergquist, "Renewing Business History," 15.

8. Rome, The Genius, 118.

9. See Krier and Ursin, Pollution and Policy, and McCarthy, Auto Mania.

10. Kantz, "Volvo's Holistic," 158; Jones, Profits, 359-360.

11. Lundqvist, The Hare.

12. Rome, The Genius, 118-119; McCarthy, Auto Mania, 171. 
occurred in 1970 when the U.S. Congress passed the Clean Air Act (CAA) amendments, which challenged large shares of the global auto industry. ${ }^{13}$ The amendments called for a 90 percent reduction of $\mathrm{HC}$ and $\mathrm{CO}$ emissions by 1975, relative to the emission levels of 1970 models. By 1976, a comparable 90 percent reduction in $\mathrm{NO}_{\mathrm{x}}$ emissions was to take place. ${ }^{14}$ Congress pushed the federal deadlines several times (until 1980-1981) due to opposition by domestic car manufacturers, while California deterred implementation of the federal deadlines until $1977 .{ }^{15}$

Volvo's new "environmental care” core value soon materialized through leadership in controlling exhaust emissions. As demonstrated in previous research, the new requirements imposed by the 1970 CAA amendments instigated a race in research and development (R\&D) efforts in the U.S. automobile industry as well as in the Japanese and European companies competing on the U.S. market, including Volvo. ${ }^{16}$ By introducing the so-called three-way catalytic converter (TWC) on the California market in 1976, Volvo became the first automobile manufacturer to show that the CAA amendment's standards were technically achievable, ahead of U.S. companies such as General Motors, Ford, and Chrysler. ${ }^{17}$ Over the course of the 1970s, Volvo not only managed to lead the development of emission control technology but also strengthened its position as a market leader in safety standards. ${ }^{18}$ A renewed strategic initiative was undertaken in the late 1980s to make the environment a cornerstone of the company, and it developed, according to previous studies, a unique company environmental profile. ${ }^{19}$

However, despite Volvo's early global leadership in exhaust emission control and safety standards, the company did not take the lead in addressing another evolving fundamental environmental problem: climate change and $\mathrm{CO}_{2}$ emissions. In 2009, Volvo was identified as the most fuel- and $\mathrm{CO}_{2}$-intensive company on the European market. ${ }^{20}$ As it appears, Volvo's environmental record has been contradictory since the 1970s. This article focuses on Volvo from the early 1970s to the 1990s. It seeks to understand the drivers behind the company's proactive environmental strategies of the 1970s and why its early environmental leadership came to a halt, while identifying evolving obstacles and disincentives that help explain this development. This study also seeks to contribute historical perspectives to the question of why the growth of the automobile industry has been difficult to align with a shift toward environmental sustainability, through the lens of Volvo.

\section{The automobile industry and exhaust emission regulation}

For more than a century, the automobile industry has revolved around a dominant design based on a combustion engine, steel body, and mechanical power train. It is well established

13. Walsh, "Automobile”; Gerard and Lave, "Implementing Technologically-Forcing Policies.”

14. Clean Air Act Amendments, 42 USC $\$ 1857$ (1970). The amendments are sometimes also referred to as the Muskie Bill.

15. Lee et al., "Forcing Technological Change," 251 f.; Bauner, "International Private," 379.

16. Bauner, "International Private."

17. McCarthy, Auto Mania, 190.

18. Tengblad, "Visionen," 68-69, 77-78.

19. Rothenberg, Maxwell, and Marcus, "Issues in the Implementation," 3.

20. It was not until 2017 that Volvo announced it would stop building models that only had a combustion engine, and that all new cars launched by the company from 2019 onward would be partially or completely battery-powered. See e.g., The Guardian, "All Volvo Cars." 
among scholars that this design has reached its limits in terms of environmental impact, especially in reducing $\mathrm{CO}_{2}$ emissions. Business and innovation scholars have highlighted some key inertial forces behind the unsustainable development of the automobile industry, whereby lock-ins and path dependencies have created great barriers to change. This occurred because the industry has been, and still is, interconnected with numerous technological systems and a complex of networks of co-specialized, interdependent, and complimentary assets. ${ }^{21}$ As a result, single automobile firms have faced strong limitations to succeeding through radical or disruptive innovations, such as alternatives to the combustion engine. ${ }^{22}$

Since the advent of the Fordist production organization, the low-cost production of automobiles on a massive scale has continued to be a paradigmatic feature of the global automobile industry. Automobile production has long been defined by cost-per-unit manufacturing, whereas consumption has been defined as the cost of cars as new, which discounts the lifetime costs of automobile use. ${ }^{23}$ Developing cars that pollute less thus involves heavy investments in $\mathrm{R} \& \mathrm{D}$, along with alterations to the automobiles' key components ${ }^{24}$ that usually increase the purchase price while only adding a few additional, direct consumer benefits. ${ }^{25}$ However, consumers have rarely prioritized environmental factors over price and other functions when buying cars. ${ }^{26}$ The weak willingness among consumers to pay a higher price for green products has constituted a critical problem for most green business initiatives in recent decades, even in several other sectors. ${ }^{27}$

Against this background, it is no surprise that previous research has identified governmental regulations, and specifically mandatory emission standards, as the single most important driver behind the greening of the automobile industry. ${ }^{28}$ At the same time, it has been shown that governmental regulation can be a double-edged sword because it can both break with or redirect current paths as well as reinforce them. Environmental regulations targeting the automobile industry have thus been a highly contested area since the 1960 s. $^{29}$ The regulatory controversy over the regional and global environmental impact of the automobile industry has shifted in scope since the 1970s, evolving into the climate change debate as well as contradictory requirements between fuel efficiency and air pollutants such as $\mathrm{NO}_{\mathrm{x}}$, and a range of other issues. $^{30}$

It is notable that the historiography on the environmental regulation of automobiles indicates different regulatory foci in Europe and in the United States. Scholars have typically

21. Unruh, "Understanding Carbon Lock-In" and "Escaping Carbon Lock-In." See also Aghion et al., "Carbon Taxes"; Geels et al., Automobility in Transition?

22. See e.g., Bento, "Is Carbon Lock-In Blocking."

23. Wells, Nieuwenhuis, and Orsato, "Nature and Causes,” 125; Calabrese, "Innovative Design,” 13-14.

24. Arp, Multiple Actors, 41.

25. Increased fuel efficiency might have a consumer benefit if its savings on fuel offset the costs of additional components, but fuel prices must be high. See Magnusson and Berggren, "Entering an Era," $316-317$.

26. Dijk, Nijhuis, and Madlener, "Consumer Attitudes."

27. Jones, Profits, 400.

28. Orsato and Wells, "The Automobile," 991; McCarthy, Auto Mania.

29. See Krier and Ursin, Pollution and Policy, and McCarthy, Auto Mania, for the United States. Car emission legislation did not cause similar contention in Europe until the late 1970s. See Boehmer-Christiansen and Weidner, Politics of Reducing Vehicle Emissions, and Wurzel, Environmental Policy-Making.

30. Bergquist, "Renewing Business History," 11. 
argued that U.S. lawmakers have prioritized clean air over fuel consumption, while European lawmakers have generally prioritized fuel efficiency over clean air, especially since the energy crises of the 1970s. ${ }^{31}$ Since the 1990s, the European and U.S. standards for exhaust pollutants have converged, although U.S. exhaust emission standards remain stricter. On the other hand, European standards for fuel efficiency and $\mathrm{CO}_{2}$ emissions are more stringent. ${ }^{32}$

One complicating factor documented in the literature concerning governmental regulations and the automobile industry has been the development of dissimilar regulatory requirements on different markets, which have required different technologies for regulatory compliance. Daniel Esty and Damien Geradin have suggested that these conditions have obstructed product development and the implementation of exhaust emission control technologies. ${ }^{33}$ One stream of literature has stressed the efforts by European automobile industry lobby associations to influence the design of European technical standards in order to protect against U.S., and later Japanese, competitors, although with little evidence regarding whether and how these associations were successful in their efforts. ${ }^{34}$

Whereas government environmental regulation targeting automobiles took its incipient steps in both the United States and Europe, including Sweden, in the 1950s and 1960s, the United States already moved much faster on emission standards in the 1970s with the 1970 CAA amendments. ${ }^{35}$ In the European Union (EEC at the time), it was not until 1989 that its member states reached an agreement on a common standard with a stringency similar to that of the CAA amendments, almost twenty years later. One greatly complicating factor in the European context was that individual countries, such as Sweden, faced obstacles to implementing a stricter and thus deviant emission control standard in relation to their European trade partners, as this would cause conflicts over nontariff barriers to trade. Across industries, various national governmental standards and goals for safety, emissions, and fuel efficiency emerged, which reflected regional and national concerns for consumer protection, along with concerns over energy conservation and energy security, particularly after the early 1970s, on both sides of the Atlantic. ${ }^{36}$

According to David Vogel and others, in the 1970s and 1980s, automakers with substantial exports to the United States, such as German and Swedish companies, had incentives to lobby their own governments to harmonize domestic regulations with U.S. standards. This occurred because these firms had invested heavily in the catalytic converter technology to comply with CAA amendments' standards, which took full effect in the early 1980s. Scholars have thus suggested that these automobile firms preferred regulatory harmonization between the

31. Klier and Linn, "VW Scandal”; Hooftman et al., “A Review,” 3; Moguen-Toursel, "Vers une coproduction."

32. Vogel, Politics, 116-118; Nesbit et al., Comparative Study, $71 \mathrm{ff}$.

33. Esty and Geradin, "Market Access," 270; Perkins and Neumayer, "Does the 'California Effect,"” 223224.

34. Ramírez-Pérez, "International Business” and "Multinational Corporations”; McLaughlin and Maloney, European Automobile Industry, ch. 6; Coen, "Environmental and Business Lobbying Alliances."

35. Walsh, "Automobile."

36. As Western governments eliminated tariff barriers to trade during the postwar period, nontariff barriers to trade became a looming concern for exporting companies. Often, product standards focused on protection of consumers' health, safety, and the natural environment. See Egan, Constructing a European Market, ch. 4; Vogel, Trading Up, 1, 13-18. 


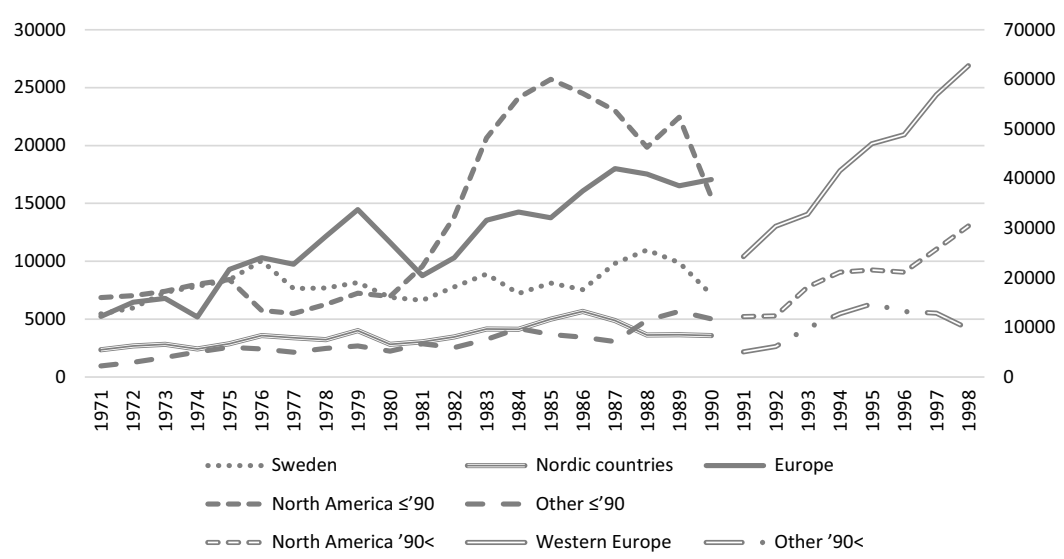

Figure 1 Volvo passenger car sales on different markets, in million SEK, 1995 prices.

Source: Volvo Annual Reports

Note: Volvo changed its regional sales reporting during the 1990s, which means that there is less information on smaller regional markets. No information on sales is available during the time of Ford's ownership. Sales in markets until 1990 $(\leq ' 90)$ are read of the left axis, while sales after the $1990(' 90<)$ are read of the right axis.

European and U.S. markets to achieve scale economies. In theoretical terms, the existence of different product standards on different markets typically increases transaction costs and generates diseconomies of scale, whereas harmonizing standards across markets can increase economies of scale for advanced emissions technology. ${ }^{37}$ This in turn meant that Italian and French firms, with marginal exports to the United States, would have been much more reluctant to adopt U.S. standards in Europe. ${ }^{38}$

Besides regulatory pressure, the impact of the OPEC oil embargos in 1973 and 1978 has attracted research attention, not least among historians. It is well established in this line of research that the oil crises of the 1970s forced automobile firms to consider fuel efficiency and alternative fuels, ${ }^{39}$ as well as electrification. Governments typically supported the automobile industry's efforts to develop alternative-fueled vehicles and alternative fuel production. A handful of studies have explored such initiatives and why they never achieved real market success. ${ }^{40}$ In the big picture, however, the combustion engine fueled by gasoline and diesel continued to overrule any alternative well into the 2010s, when the electric automobile company Tesla challenged the conventional automobile industry to seriously invest in electrification. An electric transition is still in the future, however. In 2019, battery electric and plug-in hybrid vehicles made up just 3.5 percent of new sales in Europe and just over 2 percent in the United States. ${ }^{41}$

37. Esty and Geradin, "Market Access," 270.

38. Vogel, Trading Up; Perkins and Neumayer, "Does the 'California Effect.,"

39. Wilkins, "Multinational Automobile Enterprises and Regulation,” 250. Alternative fuels are made from sources other than petroleum, such as methanol, ethanol, biogas, etc.

40. Overall, lack of demand, higher prices, lower performance compared to gasoline-fueled vehicles, poor refueling and recharging infrastructure, and the falling prices of oil in the 1980s are typical explanatory variables. See e.g., Mårald, "Methanol as Future Fuel”; Callon, "Society in the Making”; Williander, “Absorptive Capacity”; Nichols, "The Methanol Story”; Høyer, "History of Alternative Fuels.”

41. International Energy Agency, Global EV Outlook, 45, 250. 
Table 1 Production of motor vehicles by the largest automobile manufacturers, in thousands of vehicles. * Ranked after production in 1990

\begin{tabular}{|c|c|c|c|c|c|c|}
\hline Rank & Company & 1970 & 1980 & 1990 & \multicolumn{2}{|c|}{... out of which passenger cars in 1990} \\
\hline 1 & General Motors - USA & 3,594 & 4,753 & 4,223 & $65 \%$ & 2,755 \\
\hline 2 & Toyota - Japan & 1,956 & 3,293 & 4,212 & $79 \%$ & 3,346 \\
\hline 3 & Ford - USA & 2,658 & 1,888 & 2,762 & $50 \%$ & 1,377 \\
\hline 4 & Nissan - Japan & 1,396 & 3,118 & 2,479 & $82 \%$ & 2,021 \\
\hline 5 & Peugeot-Citroen - France & 577 & 1,409 & 2,153 & $92 \%$ & 1,978 \\
\hline 6 & Volkswagen-Audi - Germany & 2,221 & 2,529 & 2,020 & $96 \%$ & 1,930 \\
\hline 7 & Fiat Group - Italy & 1,644 & 1,554 & 1,821 & $90 \%$ & 1,643 \\
\hline 8 & Renault - France & 1,196 & 2,133 & 1,616 & $81 \%$ & 1,317 \\
\hline 9 & Mazda - Japan & 430 & 1,121 & 1,423 & $79 \%$ & 1,118 \\
\hline 10 & Honda - Japan & NA & 957 & 1,384 & $88 \%$ & 1,223 \\
\hline 23 & Volvo - Sweden & 221 & 286 & 291 & $85 \%$ & 248 \\
\hline
\end{tabular}

Source: World Motor Vehicle Data, various years.

* Motor vehicles include both passenger cars and commercial vehicles.

\section{Volvo Cars: A Brief Background}

Volvo was started in 1926 as a subsidiary of the Swedish multinational ball bearing company Svenska Kullagerfabriken (SKF), which introduced Volvo on the Stockholm exchange in 1935. ${ }^{42}$ Volvo's first important step was to diversify into truck manufacturing in the 1930s, which contributed to the company's production growth in its first decade of operations. ${ }^{43}$ Before World War II, Volvo's passenger car production never reached any substantial commercial achievement. It was only in 1944, when Volvo introduced the PV 444 model, marketed as "the people's car" in Sweden, that the company achieved its first market success with passenger cars. ${ }^{44}$ It was not until 1953 that passenger cars surpassed trucks as Volvo's primary source of revenue. ${ }^{45}$

Although, from the 1950s, car ownership was growing in Sweden at a higher rate than in the rest of Europe, the domestic market was still comparatively small, which drove Volvo to enter the U.S. market in 1955. Within a decade, the company managed to obtain a position as the second most important foreign automobile manufacturer on the California market, after German Volkswagen. ${ }^{46}$ Volvo's car production increased more than threefold in the 1960s, mostly due to Volvo's success in the United States. ${ }^{47}$ As the company's growth strategy was based on overseas exports, a large part of its production capacity was built up around and adapted to U.S. requirements. ${ }^{48}$

42. SKF then sold its shares in the company. Elsässer, Svensk bilindustri, $69 \mathrm{ff}$.

43. Glimstedt, Teknik och samhälle, 90.

44. Wickelgren, "En skiss över Volvos historia," 40.

45. Volvo Annual Report, 1953, 4, Swedish Royal Library (SRL), Vardagstryck.

46. Haventon, Volvo's Value Lasts, 35.

47. See Ratten: Volvos tidning, no. 2, 1970, 16, SRL. Ratten: Volvos tidning was the consumer magazine of Volvo Cars during the period 1930-2005, and was distributed to Volvo car owners in Sweden. SRL, Vardagstryck.

48. Johanson and Vahlne, “The Internationalization Process,” 27. 
Early on, Volvo adopted "quality" and "safety" as the company's "core values." ${ }^{99}$ These core values served as a compass for allocating R\&D investments in production, product technology, and brand building. From the 1950s, "safety" was given strategic priority under the leadership of Gunnar Engellau, who envisioned that safety could give Volvo a competitive advantage, not least in the United States. ${ }^{50}$ The company incorporated scientific "car safety" into its R\&D strategies in the 1950s, resulting in one of Volvo's key innovations, the three-point seatbelt, which was approved in the United States in 1961 by the Society of Automotive Engineers (SAE). ${ }^{51}$

In the early 1970s, Volvo's most important market was the United States, followed by Sweden and Britain. However, as demonstrated in Figure 1, there was a decline in exports to the United States during the oil crisis, both because the U.S. market was weakened and competition from Japanese manufacturers increased. Volvo's exports to the United States then recovered, and in the early 1980s began strongly growing, for the first time exceeding one hundred thousand cars. Volvo's strong growth in the United States was helped by the devaluations of the Swedish krona in the 1980s and the strong dollar. ${ }^{52}$

As Figure 1 also shows, Volvo's sales on European markets increased as the American market declined in the 1970s. The European market recovered more quickly from the first oil embargo in 1973 than the American market did, and it had stronger protection against Japanese competition. A newborn orientation toward Europe was manifested when Pehr G. Gyllenhammar formed the European Roundtable of Industrialists (ERT) in 1982, which played an important role during the process leading up to the 1986 Single European Act. ${ }^{53}$

As will be demonstrated later in this article, Volvo's challenges connected to environmental regulations shifted from legal compliance on the U.S. market in the 1970s to the European market in the 1980s, in which regulations required different technologies for compliance within Europe, but also in relation to the United States until the early 1990s. With growing economic integration in Europe and the creation of the European Union in 1993, and Sweden joining the European Community in 1995, the European market overall grew in importance. At the same time, the U.S. market remained a priority for Volvo. Finally, in 1999, Ford Motor Company acquired a passenger cars division, placing the company in Ford's Premier Automotive Group along with Jaguar, Aston Martin, and Land Rover. In 2010, Chinese Geely Holding Group bought Volvo from Ford. ${ }^{54}$ Since then, China has been Volvo's fastest growing market. By 2019, Volvo had grown substantially, selling 700,000 cars, 150,000 of them in China. ${ }^{55}$

49. Especially "safety." The first time this was communicated as an important value in print is in the first Volvo sales handbook from 1936: "An automobile carries, and is driven by, people. Safety is, and must be, the basic principle in all design work.” See Wickelgren, "Varumärket Volvo,” 92.

50. At this point, traffic safety had emerged as an important issue in the debate on Swedish road traffic safety. See Lundin, Bilsamhället, 152. Before the 1950s, in Volvo's vocabulary, "safety" had meant "reliability": The car would take the driver from Point A to Point B without breaking down along the way; Wickelgren, "Varumärket Volvo," 92; Palmås, ReVolvolutions, 145.

51. Volvo also developed "crash-testing” facilities together with Swedish authorities, along with a backward-facing child seat in 1967. See Palmås, ReVolvolutions, 148-149.

52. Berggren, Det nya bilarbetet, 108-109, 113-121.

53. Cowles, "Large Firms."

54. See Jönsson and Wickelgren, Volvo.

55. Volvo Annual Report 2019. https://investors.volvocars.com/annualreport2019/assets/pdf/VCG_AR_ ENG_20200326.pdf 
During the postwar period, Volvo developed into a large corporation in the Swedish, or Scandinavian, context. In 1950, the company had about 8,500 employees, but by the early 1980s this figure had expanded to 76,000. ${ }^{56}$ However, as demonstrated in Table 1, Volvo was still a very small automobile manufacturer compared to U.S., Japanese, French, German, and Italian automobile manufacturers (see Table 1). As Berggren has noted, Volvo represented a paradox from an international perspective, as the company was a small-scale producer with a very strong belief in the merits of scale. ${ }^{57}$

\section{Proactive Greening in the 1970 s}

The environmental issue developed into a top priority when Pehr G. Gyllenhammar took over Volvo's leadership in $1971 .^{58}$ Overall, the 1960s was a period of environmental awaking in Swedish industry. In 1964, the Federation of Swedish Industry already initiated a new research institute to address research and technology development to tackle industrial pollution, an initiative that was signed by the country's key industrial organizations. ${ }^{59}$ The basic reason this occurred was Swedish industry had realized that stricter and more challenging governmental environmental policies would emerge. Sweden then established its Environmental Protection Agency in 1967 and implemented a new comprehensive environmental law in 1969, while Swedish scientists were the first to raise, on the international agenda, the issue of the long-range transport of acidic compounds causing "acid rain." 60 In the early 1970s, Sweden also gained a reputation as an international leader in environmental protection when it initiated and hosted the United Nations Conference on the Human Environment, held in Stockholm in 1972; this was a milestone in the global cooperation on protecting the natural environment. ${ }^{61}$ In advance of the Stockholm conference, the Federation of Swedish Industry, in collaboration with the International Chamber of Commerce, hosted the first World Industry Conference on the Human Environment in May 1972 in Gothenburg. ${ }^{62}$

It was in this context that Gyllenhammar formed a strategy to raise Volvo's environmental profile. One strategic decision was to make "environmental care" the company's third brand value in 1972, joining "safety” and "quality." In conjunction with the Stockholm conference in 1972, Volvo also declared its first environmental policy. The policy declaration contained a broad view on the company's role in society and its responsibility toward the environment. Volvo stated that the automotive industry had been rightly accused of causing many

56. Jagrén, Företagens, 253.

57. Berggren, "Volvo: A Comeback," 420.

58. Gyllenhammar remained Volvo’s CEO until 1983, after which he became its chairman, serving until 1993. Gyllenhammar became high-profile among the European and American business elite. He had ties to the Rockefeller sphere of power, was a member of the Chase Manhattan Bank international advisory committee as well as the Henry Kissinger consultancy, and served as deputy chairman of the Aspen Institute. In 1982, he formed the European Roundtable of Industrialists (ERT), assembling leading European CEOs of various multinational corporations.

59. Bergquist and Söderholm, "Green Innovation."

60. Bergquist and Söderholm, "Green Knowledge."

61. Engfeldt, From Stockholm, 24-41.

62. Federation of Swedish Industry, Vår Industri no. 7, 1972, 33-34 SRL. 
disadvantages to human beings, including the damaging impact from air pollution, noise, and destruction of valuable landscape and city environments. Volvo also declared that it accepted its responsibility to find solutions, but-as would be argued by many business leaders in the future-the environmental requirements had to be considered against the costs. ${ }^{63}$ At the time of the Stockholm conference, Gyllenhammar established contacts with Maurice Strong, Canadian general secretary of the Stockholm conference and later secretary of the United Nations Environment Programme (UNEP). ${ }^{64}$ A delegation of the UN group was invited by Gyllenhammar for a one day session in Gothenburg to discuss the automotive industry. ${ }^{65}$ In 1973, Gyllenhammar was already involved in UNEP's planning of an international conference concerning the automobile industry's environmental challenges. ${ }^{66}$

As an automobile producer, Volvo was exposed not only to Swedish environmental regulations but also to any exhaust emission standards imposed on its export markets. Although the Swedish Environmental Protection Act of 1969 enforced strict requirements on plant emissions, particularly with respect to paint chemicals in Volvo's case, the new Swedish law did not require new standards for automobile exhaust emission control. ${ }^{67}$ The major regulatory pressure on exhaust emissions came instead from the United States, and more specifically from the state of California, where automobile emissions had been seriously debated since at least the mid-1960s.

Political scientist Lennart J. Lundqvist has argued that Sweden was more focused on, and effective at, controlling emissions from stationary sources such as industrial plants in the 1970s, while the United States led in controlling mobile sources. ${ }^{68}$ Before 1969, automobile emissions in Sweden had been separately and very loosely regulated by the Road Traffic Act of 1951. Then, in 1965, the Swedish Ministry of Transport formed a joint group of experts on automobile exhaust control, who delivered a proposal to the Swedish Government in 1968, which then issued an ordinance. The governmental ordinance specified limits for pollutants and testing methods applicable to cars beginning with model year $1971 .{ }^{69}$ The method was based on the newly developed European test cycle. Pollutant limits set in Sweden in 1968

63. Called Mobility and the Environment. The Volvo View, from 1972.

64. They corresponded frequently on a friendship basis in the 1970s, and their families took joint holidays. Maurice Strong Papers, Box 147 and 124, Environmental Science and Public Policy Archives, Harvard Library (HL).

65. Pehr G. Gyllenhammar, digital interview by Ann-Kristin Bergquist, November 19, 2020.

66. “Motor Industrialists to Meet in Nairobi to Discuss Pollution,” Daily Nation, November 15, $1973,3$.

67. See e.g., Palmås, who in ReVolvolutions, 165, mentions that the first instance of criticism related to environmental issues resulted from roadside littering. The first major challenge came when Volvo applied for a license to expand car production at its Torslanda production plant in 1979, which called the Swedish environmental authorities' attention to significant amounts of emissions of hydrocarbons (HC), 3,400 tons per year, resulting primarily from the car painting process, which would increase as production increased. Volvo eventually acquired the license, with the stepwise requirement to decrease annual HC emissions to 450 tons by 1998. See the licensing acts in Koncessionsnämnden för miljöskydd, Dnr. 60/79; 257/79; 888/90; 435/91, Swedish National Archives (SNA). According to Inge Horkeby, in order to achieve this extreme reduction, Volvo developed a radically new water-based automotive paint, which was later adopted by other automobile manufacturers around the world. Inge Horkeby, interview by Mattias Näsman. August 22, 2017, Gothenburg; see also Rothenberg and Maxwell, "Extending the Umbrella."

68. Lundqvist, The Hare, 194.

69. Swedish Code of Statutes, SFS 1968: 726, and SFS 1968: 728. See also Lundqvist, The Hare, 48-49. 
were stricter than European requirements but less strict than U.S. standards. ${ }^{70}$ In 1970, Volvo, which had been involved in the joint group of experts, was already able to meet the exhaust emissions required by Swedish law through engine modifications. ${ }^{71}$

The situation for Volvo changed dramatically in 1970, when the U.S. Congress passed the CAA amendments. ${ }^{72}$ The amendments called for 90 percent emission reductions in $\mathrm{HC}$ and CO by 1975, relative to the emission levels of the 1970 models. By 1976, a comparable 90 percent reduction in $\mathrm{NO}_{\mathrm{x}}$ emissions was to take place. ${ }^{73}$ This short time span meant that mere engine modifications were not sufficient for compliance but that automakers with sales on the U.S. market had to equip new cars with catalytic converters by $1975 .{ }^{74}$ Therefore, the standards were technology forcing and sent shock waves across the industry. Basically, two business reactions took hold: actions to delay the American Environmental Protection Agency's (EPA) implementation of the standards on the one hand, and actions to develop technology to comply with them on the other.

In 1972, International Harvester, Ford, Chrysler, General Motors, and Volvo filed for suspension, but the EPA denied their request. The companies then took the case to court and argued that the technology necessary to meet the requirement for the 1975 model would not be available before 1975. In 1973, the U.S. Court of Appeals for the District of Columbia remanded the decision to the EPA, who was instructed to hold hearings again in March 1973. The deadline for $\mathrm{CO}, \mathrm{HC}$, and $\mathrm{NO}_{\mathrm{x}}$ reductions was pushed forward one year (to 1976/1977), while less strict interim standards were implemented. ${ }^{75}$ In 1975, the EPA once again pushed the standards for HC and CO to 1978, while the CAA standards for California were postponed until $1977 .{ }^{76}$ As it happened, this dramatic process coincided with oil crises and Congress's decision in 1975 to introduce corporate average fuel efficiency (CAFE) standards by 1978. The CAFE standards initiated a parallel investment race among General Motors, Ford, and Chrysler on the scale of the Apollo program. ${ }^{77}$ By 1977, the U.S. manufacturers could still not comply with the CAA amendments of 1970, and Congress was forced to postpone the final deadline until 19801981 through the new CAA amendments of 1977, while $\mathrm{NO}_{\mathrm{x}}$ standards were relaxed. Otherwise, the U.S. automobile industry would have literally been prohibited by law from selling cars. ${ }^{78}$

70. Swedish Ministry of Transportation, Avgaser, 80-81.

71. Palmås, ReVolvolutions, 166. For a summary of the work of the joint expert group and its members, see Swedish Ministry of Transportation, Luftföroreningar, 31-36.

72. Walsh, “Automobile”; Gerard and Lave, "Implementing Technologically-Forcing Policies."

73. Clean Air Act Amendments, 42 USC § 1857 (1970).

74. See e.g., McCarthy, Auto Mania, 176; Walsh, “Automobile,” 144; Mondt, Cleaner Cars, 140. Whereas the law was technology-neutral, the automobile companies quickly realized that the catalytic converter technology was the most promising option for achieving the emission reduction specified by the CAA amendments.

75. Gerard and Lave, "Implementing Technologically-Forcing Policies," 769-770, 772.

76. The OPEC oil embargo of 1973 placed the abatement of automobile pollution on a collision course with fuel-shortage issues, because catalytic converters increased fuel intensity. See Lundqvist, The Hare, 134. This led the Senate to propose an extension of the deadlines for introducing the standards to 1977 for HC and CO, and to 1978 for $\mathrm{NO}_{\mathrm{x}}$. This bill was not completed, however. To grant the time to allow automakers to focus on greater fuel economy instead of pollution abatement, Congress proposed a new bill to extend the deadlines for HC and $\mathrm{CO}$ to 1977, and to 1978 for $\mathrm{NO}_{\mathrm{x}}$; this was signed into law by Nixon in 1974. See Lundqvist, The Hare, $135-137$.

77. The investments amounted to $\$ 80$ billion, out of which General Motors invested $\$ 45$ billion. Jones, Maturity and Crisis, 8-16.

78. Gerard and Lave, "Implementing Technologically-Forcing Policies," 773. 
In this context it is important to mention that the introduction of unleaded gasoline across the United States was crucial, as lead destroys the catalysts' abilities to abate harmful emissions. As General Motors announced early on that catalysts were necessary in order to comply with the CAA amendments' standards, the U.S. EPA managed to mandate the introduction of unleaded gasoline. ${ }^{79}$

\section{The Invention of the Three-Way Catalytic Converter and the Oil Crisis}

As mentioned, the amendments of 1970 were technology-forcing and spurred R\&D efforts in the U.S. automobile industry and other companies with sales to the United States, including Volvo ${ }^{80}$ In 1970, Volvo already made a strategic decision to develop technologies for compliance as quickly as possible, rather than wait to see whether or not the new legal requirements would be postponed. ${ }^{81}$ Volvo needed to be at the technological frontier, or it ran the risk of being denied access to the U.S. market and a quarter of its total sales. ${ }^{82}$ The challenge was to find a solution that did not compromise consumer-based considerations such as drivability, performance, fuel efficiency, and price. ${ }^{83}$ After Gyllenhammar took over Volvo's leadership in 1972 , funding for R\&D was poured into the project. ${ }^{84}$

In late 1972, Volvo and other manufacturers were mainly betting on systems containing two catalysts: one oxidation catalyst to reduce $\mathrm{CO}$ and $\mathrm{HC}$ emissions and one reduction catalyst, placed between the engine and the oxidation catalyst, to abate $\mathrm{NO}_{\mathrm{x}}$. As the reduction of $\mathrm{NO}_{\mathrm{x}}$ required rich air-fuel mixtures while the oxidization of $\mathrm{CO}$ and $\mathrm{HC}$ required engines to run lean, ${ }^{85}$ there were major challenges related to the control of the fuel mix and high fuel consumption, besides the need to install two catalysts instead of one. ${ }^{86}$ At the beginning of 1973, Volvo's engineers had a couple of solutions ready for implementation, but the best technology turned out to be a single three-way catalytic converter combined with the so-called Lambda sensor. At the time, catalytic converters were widely used in the processing industry, while Lambda sensors were used in industrial combustion plants. The Lambda sensor, developed by German Bosch, was a device that regulated the optimum amount of oxygen in combustion. ${ }^{87}$ At an early stage, Stephen Wallman, who was in charge of Volvo's R\&D team, contacted Bosch and the American Engelhard Minerals and Chemical Corporation to suggest a collaboration. Engelhard had already developed a catalytic converter in 1964 to abate CO from the exhaust of gasoline- and propane-fueled vehicles in Swedish

79. Needleman and Gee, "Lead in Petrol," 60. See also McCarthy, Auto Mania, ch. 9.

80. Bauner, "International Private."

81. Stephen Wallman, digital interview by Mattias Näsman and Ann-Kristin Bergquist, February 24, 2016.

82. Ibid.; Volvo Annual Report, 1972, 10, 35, SRL.

83. Stephen Wallman, digital interview by Mattias Näsman and Ann-Kristin Bergquist, February 24, 2016.

84. Palmås, ReVolvolutions, 167-168.

85. Rich air-fuel mixtures are fuel-rich, whereas lean mixtures are air-rich.

86. United States Environmental Protection Agency (U.S. EPA), State of the Art, 3-1, 4-1.

87. Lambda $(\lambda)$ is the so-called air-fuel equivalence ratio, calculated from the actual air-fuel ratio divided by the theoretical air-fuel ratio for optimum combustion (stoichiometry). The Lambda sensor thus measures the actual air-fuel ratio, and sends a feedback signal to the injection system to bring the Lambda closer to 1, which is theoretically optimum combustion. 
mines, ${ }^{88}$ and worked closely with U.S. automakers and the EPA in the late 1960s and early 1970s.

In Volvo's test trials, the TWC and Lambda sensor demonstrated, in short, the highest emission control, performance levels, and fuel efficiency at a relatively small cost, besides offering the benefit of needing only one catalyst. ${ }^{89}$ In the fall of 1976, more than a year before the contemporary deadline of the CAA amendments' standards, Volvo introduced on the California market a Volvo 2241977 model equipped with the TWC. In practice, this meant that Volvo had managed to meet the California standards ahead of the deadline. ${ }^{90}$ Although other companies, such as BMW, Renault, Saab, Volkswagen, and Peugeot, had also been working on the use of three-way catalysts to meet the 1976 standards, while Honda and Daimler-Benz worked on other solutions, Volvo ultimately won the race. ${ }^{91}$ The buyer of the first ten Volvo cars equipped with the new catalytic converter was the California Air Resources Board. The board used the car model to demonstrate to American manufacturers that it was possible to comply with the CAA requirements, and questioned them regarding their sluggishness. Chrysler, Volvo's second customer, bought ten cars. ${ }^{92}$ The second automaker to introduce the same catalytic converter was Swedish Saab, while Porsche became the third; after this, virtually all other companies on the U.S. market followed suit. ${ }^{93}$ In 1977 , the U.S. EPA awarded Volvo the National Environmental Industry Award for its achievement. ${ }^{94}$

For Volvo's image, being the automobile company that introduced the TWC on the U.S. market was a historic moment. While U.S. automobile manufacturers had fiercely fought new environmental regulation in the $1970 \mathrm{~s},{ }^{95}$ Volvo had changed the rules of the game and the bargaining power of the U.S. EPA. ${ }^{96}$ U.S. lawmakers and the EPA actively used Volvo to showcase that it was actually possible to meet the original 1970 CAA amendments' standards, despite the U.S. industry's position that it could not be done. ${ }^{97}$ For the U.S. EPA and the environmental movement, Volvo symbolized a David in the battle against Goliath.

In 1973, at the same time the car industry was seriously challenged by the CAA, the first OPEC oil embargo occurred. The oil crisis also coincided with the 1972 publication of the book Limits to Growth by the Club of Rome, which raised strong concerns about environmental limits to growth, although the notion of environmental "limits" was already on the agenda at the Stockholm conference in $1972 .{ }^{98}$ Gyllenhammar was concerned by the "limits" debate and

88. McCarthy, Auto Mania, 176.

89. U.S. EPA, State of the Art, 6-170; Stephen Wallman, digital interview by Mattias Näsman and AnnKristin Bergquist, February 24, 2016.

90. U.S. EPA, Development Status ... 1976, 7-437.

91. U.S. EPA, State of the Art, 3-4, 6-1 ff. Early on, Honda focused on developing its CVCC engine, while Daimler-Benz focused on diesel technology.

92. Stephen Wallman, digital interviewby Mattias Näsman and Ann-Kristin Bergquist, February 24, 2016.

93. Ibid.

94. Volvo Annual Report, 1976, 10, SRL.

95. Rome, The Genius, 118.

96. See Krier and Ursin, Pollution and Policy, and McCarthy, Auto Mania.

97. "The important point about these results is that they show for the first time, a vehicle run on official EPA certification durability that came close to meeting the statuary standards." U.S. EPA, Development Status 1976, 7-439.

98. The book Only One Earth by Barbara Ward and René Dubos had been distributed to the delegates before the conference. 
believed - at the time- - that the ceasing of oil resources would pose a major threat to the auto industry and transport if no plausible alternatives were obtained. ${ }^{99}$ Like governments and industries around the world, Volvo hence began to look for alternatives to possibly supplement or replace oil. ${ }^{100}$

In 1974, Volvo started investigating options for alternative fuels, and negotiated with the Swedish Government to form a joint venture to develop methanol as a motor fuel. Gyllenhammar presented a plan for investment in methanol production to the minister of industry the same year. In 1975, the Swedish Methanol Development Company was established as a joint venture between Volvo and the Swedish state. The main objective was to secure methanol for civil society in cases of emergency, such as war. An advantage of methanol was its liquid form, which meant it could be stored and distributed within the existing gasoline distribution infrastructure. It was also important that it could be used in ordinary internal combustion engines through small modifications. In other words, as an alternative to gasoline, methanol could be smoothly linked to the internal combustion engine/oil trajectory within the established socio-technical systems. ${ }^{101}$ Sweden, however, did not have the domestic natural resources needed for methanol production, such as natural gas, which was the reason why Gyllenhammar initiated discussions with the Norwegian state to get access to the fields of natural gas and oil in the Atlantic Ocean. ${ }^{102}$ In 1978, Volvo started negotiations with the Norwegian state involving a fusion between Volvo and the state-owned oil company Statoil. The idea was to secure petroleum resources for Volvo, while Volvo helped to develop the engineering and mechanical industry in Norway. ${ }^{103}$ In exchange for Volvo shares, the Norwegian state would give the company access to Norway's continental shelf. However, Volvo's shareholders ultimately voted against the deal, and the transaction between the Norwegian state and Volvo never became reality. ${ }^{104}$

Different events coincided in the 1970s that created great concern regarding the future security of oil, but all in all, this did not lead Volvo to change course from fossil fuels and the combustion engine. The company had met the environmental requirements in the United States, and the company achieved goodwill for this. At the same time, Volvo made progress in the area of safety during the 1970s. In 1972, the company introduced the Volvo Experimental Safety Car (VESC), a concept car equipped with antilock brakes and airbags, along with other safety equipment. ${ }^{105}$ In 1978, the U.S. National Highway Traffic Safety Administration (NHTSA) chose Volvo's VESC concept-based 240 model as the benchmark for testing crash safety in the United States. ${ }^{106}$ Volvo's safety technologies formed the basis of safety policies not only in the United States but also in Sweden, which secured the company's position as the spearhead of safety innovations. ${ }^{107}$

99. Gyllenhammar, Jag tror, 127.

100. See n. 40 for references.

101. Mårald, "Methanol as Future Fuel," 341.

102. Pehr G. Gyllenhammar, digital interview by Ann-Kristin Bergquist, November 19, 2020.

103. Ibid. See also Mårald, "Methanol as Future Fuel," 342-343.

104. Hökerberg, Spelet om Volvo, 54-55.

105. Tengblad, "Visionen," 68.

106. Wickelgren, "Varumärket Volvo," 93.

107. Ibid. 


\section{Regulatory Roadblocks to Greening in the 1980s}

Although Volvo spearheaded the development of exhaust emission control in the United States, the company was both unable and unwilling to take advantage of this technology in Sweden and elsewhere in Europe. The key issue was that vehicles equipped with a catalytic converter could only run on unleaded fuel. In the United States, the EPA demanded that gas stations provide unleaded gasoline, whereas no such decisions or agreements had been reached in Europe in the early 1980s. In practice, this meant that vehicles equipped with a catalytic converter could not be used until unleaded gasoline was provided. Of course, these circumstances applied to all carmakers with sales in Europe.

As will be explained below, Volvo did not pressure or even support the Swedish Government in setting the stringent U.S. standards before an agreement on the matter was reached within the EEC. Although scholars such as Perkins and Neumayer have argued that internationally oriented firms have incentives to maximize economies of scale for abatement technology by lobbying domestic governments to implement standards in parity with the standards on the firms' primary export markets, ${ }^{108}$ this is not what happened in the Volvo case.

Already, in December 1972, the Swedish Government decided to move closer to the CAA amendments' standards. ${ }^{109}$ Through this decision, the Swedish standards would diverge even more from the European ones in terms of stringency. Volvo argued that, although tighter standards were justified from an air quality perspective, severe problems would arise if the Swedish standards were disharmonious with those in the rest of Europe. ${ }^{110}$ In 1979, when the Swedish Royal Commission on Exhaust Emissions discussed the possible introduction of U.S. standards requiring catalytic converters and unleaded gasoline in Sweden, Volvo strongly opposed this, even though the company already had the technology available. ${ }^{111}$

Gyllenhammar launched a number of arguments. One of them, which was also supported by the labor unions, was the fact that if catalytic converters became mandatory in Sweden, Swedish motorists would not be able to drive their vehicles outside the country's borders if neighboring countries did not provide unleaded gasoline. Another argument was that car prices would increase significantly. A more complex argument concerned trade relations: If Sweden imposed stricter standards than the rest of Europe, this would mean that, in practice, Sweden would raise technical barriers regarding other European automobile manufacturers. Gyllenhammar feared that this would lead to a situation in which other European countries retaliated by overall restricting imports from Swedish companies. ${ }^{112}$

Due to the risk of disrupting the single market, the European Economic Community (EEC) Commission did indeed set upper and lower limits of lead in fuel in 1978, to take effect in 1981,

108. Perkins and Neumayer, "Does the 'California Effect,"” 223-224.

109. Swedish Code of Statutes, SFS 1972: 596.

110. Ratten: Volvos tidning, no. 1, 1972, SRL. See also the statement by Volvo's Gerhard Salinger to the joint Swedish Ministry of Transport's committee on exhaust emissions, Swedish Ministry of Transportation, Luftföroreningar, 223.

111. Swedish Ministry of Agriculture, Bilarna och luftföroreningarna.

112. Bilavgaskommittén 1977-1984, box 5, Remisshandlingar till SOU 1979:39 m.m., SNA; "Yttrande rörande bilarna och luftföroreningar, SOU 1979:34," annex 13, SNA. 
which restricted all member states from introducing unleaded gasoline. ${ }^{113}$ Although Sweden was not a member of the EEC, Sweden and Volvo still had to consider the EEC trade policies. Indeed, the expansion and harmonization of the common European market forced Volvo to be cautious of Swedish unilateral initiatives. The fact that Gyllenhammar was one of the driving industrial forces behind the European integration through his ERT initiative also reflected the fact that the European market had increased in significance. ${ }^{114}$

In May 1984, the EEC Commission proposed that member states be allowed to mandate the availability of unleaded gasoline by 1986, and required an introduction of unleaded gasoline beginning in 1989 across the EEC. ${ }^{115}$ In December 1985, Sweden finally made the decision to adopt U.S. standards by 1989, which required the use of the TWC technology. ${ }^{116}$ The European Council, Commission, and Parliament decided upon similar standards for all new cars in 1989, effective from 1992, including the smaller cars that had been allowed more lax requirements by a council decision in 1985. ${ }^{117}$ According to Vogel, difficulties in finding common ground for regulation in the EU mainly rested on the fact that there were differences in automobile production among the member states, as well as in their experiences with the American market and catalytic converters. ${ }^{118}$

When the decision was finally made regarding strict emission requirements in Sweden, Volvo could finally make use of the TWC technology on the Swedish market. Volvo delivered cars with catalytic converters to Swedish customers as soon as unleaded gasoline was available in 1987, and in the last edition of the Volvo magazine Ratten in 1986, almost all the space was devoted to the catalytic converter. ${ }^{119}$ A postscript to the 1986 annual report reported for the first time on Volvo's past environmental achievements, especially highlighting the catalytic converter. ${ }^{120}$ From this point on, Volvo also tried to reinforce an environmental image at home in order to portray the company as a reigning environmental pioneer.

In 1988, Volvo adopted a renewed environmental strategy, which, according to studies by the management scholar Sandra Rothenberg and coauthors, represented the "most comprehensive and proactive environmental strategy in industry" at the time. ${ }^{121}$ However, this strategy did not embrace the issue of vehicle emissions; rather, it focused on controlling emissions from plants. The new strategy was a response to a public embarrassment when Volvo's subsidiary companies had violated Swedish environmental regulation. In the wake of this scandal, Inge Horkeby, Volvo's chief environmental manager from 1987 to 2015, recognized a need for a comprehensive environmental strategy throughout the whole Volvo Corporate Group. Volvo had rapidly diversified beginning in the late 1970s, and had acquired,

113. Vogel, Politics, 113.

114. In 1982, in consultation with European Commissioner for Industry Etienne Davignong and with the support of Umberto Angnelli of Fiat and Wisse Dekker of Phillips, Gyllenhammar drew together a cross-sectoral group of leading European CEOs to form the European Roundtable of Industrialists (ERT). The alliance between the European Commission and the ERT played a historical role in the process leading up to the 1986 Single European Act. See Cowles, "Setting the Agenda." Gyllenhammar was the chairman for the ERT 1983-1988.

115. Walsh, "Automobile," 149.

116. Swedish Governmental Bill 1986/87:56; Swedish Code of Statutes, SFS 1986:1386.

117. Nesbit et al., Comparative Study, 23; Vogel, Trading Up, 67-77.

118. Vogel, Politics, 108-111.

119. Ratten: Volvos tidning, no. 4 1986, SRL.

120. Volvo Annual Report, 1986, 56-57, SRL.

121. Rothenberg, Maxwell, and Marcus, "Issues in the Implementation," 2. 
among other businesses, a number of foodstuff companies managed under the holding company Provendor. When a sugar manufacturing company violated its environmental emission permit, severely damaging a water treatment plant along the southern Baltic Sea, it became a scandal in Swedish media. Gyllenhammar was highly annoyed by the situation and called together a new group, Task Force: Environment, consisting of all the chief executives of the various subsidiary companies within the Volvo Corporate Group. ${ }^{122}$ Meanwhile, Volvo bought a twelve-page advertisement in British Time Magazine in 1989, portraying Gyllenhammar as "Volvo's green voice," who showed an "almost missionary zeal on green issues." ${ }^{123}$ Volvo additionally raised its green profile by instituting the Volvo Environmental Prize in 1989. Although the company boosted its "green" corporate communication in the late 1980s, this rhetoric was not reflected in the cars it planned to produce in the future.

\section{Toward Premium Greening in the 1990s}

The start of the 1990s was critical for Volvo in several ways. Sweden entered a deep economic crisis in 1990, which lasted through 1994, and a failed merger with French Renault in 1993 caused Gyllenhammar, who was then the chairman of Volvo, to resign. ${ }^{124}$ By then, he had built an impressive reputation for himself and Volvo. For nine consecutive years prior to his resignation, he held the title of "Sweden's most admired man." ${ }^{125}$ Gyllenhammar's strategic thinking has been characterized as "focused on grand deals, alliances, and diversification," with little interest for the automobile business as such. ${ }^{126}$ The Renault deal was heavily criticized by top managers, engineers, and shareholders, who feared that state-owned Renault would gain too much control. ${ }^{127}$

After the failed merger with Renault, Volvo was forced to rethink its image. As others in the automotive world, the company turned toward lean production with shorter lead times and higher levels of flexibility to catch small shifts in demand, while divesting its nonautomotive businesses. ${ }^{128}$ Its targeted customers were now labeled "affluent progressives." 129 These newly targeted consumers were the quickly growing class of well-educated, well-off, liberal intellectuals, who valued safety and were concerned about the environment. The former selling points, which had stressed high secondhand value and durability and had appealed to the consumer's rationality, were now giving way to more emotionally laden aspects such as identity. Additional effort was put into design for a more visually pleasing experience, along

122. Inge Horkeby, interview by Mattias Näsman, August 22, 2017, Gothenburg. A year later, the group published a strategy for all the companies in the business group, which was highly diversified at the time, containing environmental goals, strategies, monitoring systems, training activities, etc. See Rothenberg, Maxwell, and Marcus, "Issues in the Implementation," for a thorough analysis of this strategy.

123. "We Can Save the Earth. Special Advertising Section," Time International Edition, November 27, 1989.

124. In 1990, Gyllenhammar was replaced by Christer Zetterberg as Volvo's CEO.

125. A documentary with the same title, Sveriges mest beundrade man, aired on Swedish television in 2018.

126. Berggren, "Volvo: A Comeback," 428.

127. For an accounting of the failed merger between Volvo and Renault, see e.g., Bruner and Spekman, "The Dark Side."

128. Wickelgren, "En skiss över Volvos historia," 48.

129. Wickelgren, "Varumärket Volvo," 104. 
with greater focus on driving pleasure and low-maintenance ownership. To accompany this change toward premium branding, Volvo further followed a hard rationalization plan and changed its corporate communication. ${ }^{130}$ In 1994, Sören Gyll, the Volvo CEO since 1992, presented to the annual shareholder meeting an action plan that emphasized a clearer focus on strengthening the company's global network. Within the network, the company's brand should be more clearly communicated using Volvo's core values: quality, safety, and environmental care. ${ }^{131}$

In the late 1980s and early 1990s, the environmental debate changed its characteristics, and new targets were set for Swedish environmental policy. More laws and increasingly stringent requirements were added to existing environmental regulations. According to the Swedish Government, a more holistic approach was needed that would cover the environmental impact not only of production but also of the product itself, "from cradle to grave." Life cycle analysis-evaluating the total environmental impact of material and energy flows in the production, use, and disposal of a product-arose as part of this development. ${ }^{132}$ The 1980s also saw the emergence of the issue of ozone depletion, which resulted in the Montreal Protocol in 1987 and a phaseout of chlorofluorocarbons (CFCs).

In the 1990s, Volvo worked toward compliance with new Swedish regulatory requirements, for instance by developing a declaration of contents to make car recycling easier. The company also developed a CFC-free refrigerant, for which Volvo was awarded the Ozone Protection Award by the U.S. EPA. ${ }^{133}$ In order to meet the requirements of the 1994 Swedish Producer Responsibility Act-a law that made manufacturers responsible for recycling their own products-Volvo also established improved methods for recycling. ${ }^{134}$ In 1996, the Swedish Government enacted a special act regulating producers' responsibilities with respect to discarded automobiles, demanding that by 2002, 85 percent of the weight of each automobile should be possible to recycle. ${ }^{135}$ But overall, there was no regulatory push for lower exhaust emissions stemming from Swedish or European regulation in the 1990s. Instead, once again the initiative came from the state of California in the United States.

In 1990, the California Air Resources Board (CARB) issued the zero-emission vehicle (ZEV) mandate, along with other, less strict targets for low-emission vehicles. The mandate required that 2 percent of an automobile company's sales be of the ZEV type by 1998, with the share increasing to 10 percent by 2003. Although this regulation was technology-neutral, only battery electric vehicles (BEV) could come close to zero emissions. CARB was inspired to require emission-free vehicles by GM's unveiling of its Impact, a BEV prototype, which promised to substantially improve the performance of BEVs. CARB understood that the development of electric vehicles still needed time to be fully commercially viable, but the

130. Wickelgren, "En skiss över Volvos historia," 48-50.

131. Olsson and Moberg, Volvo. Gothenburg. Sweden, 231.

132. Bergquist, "Dilemmas," 165.

133. Volvo Environmental Data Report, 1994, 8. See also Ratten: Volvos tidning, no. 3, 1990, 42, SRL. CFCs cause the ozone layer to be depleted. International agreements, such as the Montreal Protocol, which came into force in 1989, contributed to reducing CFC emissions and stopped the depletion of the ozone layer, which is now showing signs of repair.

134. Ratten: Volvos tidning, no. 3, 1994, 20-21, SRL.

135. Swedish Governmental Bill 1995/96:174. 
board also distrusted automobile manufacturers and decided to force the development. The U.S. "Big Three"-GM, Ford, and Chrysler-thus had to invest heavily in R\&D for BEVs, but they fought the mandate through law and politics—a strategy reminiscent of the 1970s. ${ }^{136}$

Aiming to comply with the new rules in California, Volvo developed the Environmental Concept Car (ECC), which was launched in 1992. The ECC was the first hybrid Volvo developed. It had a diesel-driven gas turbine, and its interior featured natural materials such as cork, along with low-weight materials such as aluminum in the car body, which would make it lightweight and easy to recycle. ${ }^{137}$ Volvo's ECC won international awards and gained international attention, which again strengthened its reputation as an environmentally conscious brand. The ECC represented the vision of a "catchall" solution in private motoring, indicating that it was possible to be a friend of the environment without sacrificing the comfort or safety that consumers were now used to. ${ }^{138}$ However, most concept cars aiming for ZEV were never intended to be commercialized in the first place. According to Leif Fredrickson, who studied Ford and the ZEV mandate, green marketing was one way to influence regulatory development by projecting a public image as authoritative experts in environmental technologies. Ford was the most vocal opponent of the ZEV mandate, but at the same time developed the Ecostar, a $\mathrm{BEV}$ that was never meant to be mass-produced. With the Ecostar, Ford only wanted to project the image that the company was a leader in electric vehicle technology. In portraying itself as an authoritative leader in BEV technology Ford hoped to persuade the public to back its efforts to weaken the mandate, albeit under false pretenses. ${ }^{139}$ Although Volvo did not develop its own line of hybrid or electrical engines for a long time, it certainly used marketing to convince its stakeholders of its environmental technology expertise.

\section{Climate Change and Heavier Cars}

Before 1995 Volvo did not treat human-induced climate change as an issue that the company had a responsibility to address, although there already was an awareness of the problem in the 1970s. At a seminar organized by the Swedish Commission of Transport Research in 1977, one of Volvo's engineers gave a presentation that included a forecast regarding the relationship between $\mathrm{CO}_{2}$ emissions and $\mathrm{CO}_{2}$ concentration in the atmosphere and rising temperatures by the years 2000, 2050, and 2100. ${ }^{140}$ Although most countries joined the UN Framework Convention on Climate Change in 1992, it was not until 1993 that the company began monitoring $\mathrm{CO}_{2}$ emissions from its production plants. It was 1995 when Volvo finally addressed climate change as a real threat in its environmental data report. ${ }^{141}$ Improved fuel efficiency, rather

136. For a thorough account of the ZEV mandates and the responses of the automobile industry, see Collantes, "Zero-Emission Vehicle"; Collantes and Sperling, "The Origin”; Fredrickson, "Rise and Fall of an Ecostar"; Eisler, "Public Policy."

137. Haventon, Volvo's Value Lasts, 68-69.

138. Ratten: Volvos tidning, no. 3, 1993, 40-41, SRL.

139. Ford had little success in its efforts to weaken public support for the ZEV mandate, in Fredrickson's view. Fredrickson, "Rise and Fall of an Ecostar," 142. Eisler, who has looked at General Motors and Toyota, argues that the automobile industry was effective in watering down the technical requirements of the ZEV mandate. See Eisler, "Public Policy."

140. The forecast was based on IIASA calculations. See Norland, “Tillgången på olja,” 24.

141. Volvo Environmental Data Report, 1995, 5, 14-19. 
than electrification or other alternatives, was seen as the most promising way to reduce the climate impact of Volvo's cars. ${ }^{142}$ However, at the same time, the company's marked focus on large, heavy cars in the premium segments made this strategy difficult to pursue in practice.

In Sweden, the Swedish Road Administration changed the rules for company car taxation in 1997, excluding all cars using more than 0.86 liters per 10 kilometers. This dismissed many of Volvo's models produced in Sweden, which was a blow to its green image. In 1997, Leif Johansson, newly appointed CEO of Volvo Corporate Group, made a promise to lower the company's fuel intensity 25 percent by 2005, compared to 1990. This goal was only aimed at cars sold within the European Union, not the United States. ${ }^{143}$ Lowering fuel and $\mathrm{CO}_{2}$ emissions from cars had never been Volvo's first priority in its R\&D programs. $\mathrm{CO}_{2}$ emissions-which is a proxy for fuel intensity-from Volvo's cars dropped only 9 percent between 1970 and $1995 .{ }^{144}$ The goal to reduce the fuel intensity of cars sold within the EU was later changed to 25 percent for the period 1995-2008, which followed from a voluntary agreement between members of the European Automobile Manufacturers Association (ACEA) and the European Commission. ${ }^{145}$

Since 1978, when fuel use began being monitored in Sweden, Volvo and Saab were the most fuel-intensive brands on the Swedish market. From 1978 and throughout the 1990s, Volvo's car fleet was 8 percent more fuel intensive than the average car. ${ }^{146}$ Up to the late 2000s, Volvo was in fact the least fuel-efficient brand on the whole European market. ${ }^{147}$ The company's long-term R\&D focus on spacious family cars, along with sporty cars and SUVs from the 1990s, drove Volvo to the top of the fuel intensity list on the European market. ${ }^{148}$ Among Volvo's top selling cars, the 144 DL (1973) used 1.20 liters per 10 kilometers, the 240 (1983) used 0.94 liters, the 850 (1993) used 0.87 liters, and the V70 140 (2003) used 0.91 liters. ${ }^{149}$ Clearly, there were trade-offs between the company's premium product range and fuel efficiency, while its high ambitions for safety standards also added weight. Volvo experienced little market pull from its major markets to develop technologies outside high-performance gasoline engines. ${ }^{150}$ In 1997, close to half of all its cars were sold in the United States, Sweden, and the UK, where diesels made up only a tiny fraction of the market. ${ }^{151}$ For other European companies such as Citroen, Peugeot, Renault, Fiat, and Volkswagen, the choice of diesel technology was easier as they had all but abandoned the U.S. market to Japanese competition in the 1990s. ${ }^{152}$ Moreover, Volvo lacked the financial muscle to independently develop complex new hybrid-electric

142. The report emphasized that gasoline and diesel technologies would dominate the fuel market for many years to come, while electric hybrids might be an alternative for shorter distances. See Volvo environmental data report, 22, 25.

143. Ratten: Volvos tidning, no. 4, 1997, SRL; Ratten: Volvos tidning, no. 2, 1998, 19, SRL.

144. Volvo Environmental Data Report, 1995, 25.

145. Volvo Environmental Data Report, 1998, 6.

146. Bilismen i Sverige, various years.

147. EEA, "Monitoring," 20.

148. Berggren and Magnusson, "Reducing Automotive Emissions," 637.

149. Mikael Stjerna, "Bilförsäljningen 1973-2003: Dyrare, starkare och snabbare," Teknikens värld, no. 3, 2004, 54-56.

150. Stephen Wallman, digital interview by Mattias Näsman and Ann-Kristin Bergquist, February 24, 2016.

151. Volvo Annual Report, 1998, 27, SRL.

152. Rosegger, "Interfirm Cooperation," 702. 
drivetrains after the failed Renault merger, whereas under Ford it relied on existing engineering practices. ${ }^{153}$

Regional dynamics influencing technology choice might partly explain Volvo's poor performance in fuel efficiency. Berggren et al. have argued that Japanese companies, particularly Toyota, started developing gasoline-electric hybrid engines in the 1990 s as a response to rising concerns over $\mathrm{CO}_{2}$ emissions and urban air quality issues, along with projections of oil shortage and rising fuel prices. Toyota's first hybrid Prius was introduced on the Japanese market in 1997 and in the United States in 2000. Hybrids enjoyed some success in the United States as fuel prices started to climb, but still only captured 1.6 percent of the market in 2006. In Europe, on the other hand, diesel technology became more popular for reaching fuel efficiency goals, after a series of innovations sprung out of the 1990s that improved performance, convenience, and, not least, emission control in diesels. ${ }^{154}$

Although fuel efficiency, and hence $\mathrm{CO}_{2}$, remained a problem, Volvo followed the general trend of boosting green communication to stakeholders. Volvo's environmental data, reported since 1991, demonstrate that environmental information and statistics became more detailed and extensive in 1995, with the number of pages doubling from 1994 to 1995. Since 1993, the reports have been signed by Volvo's executives, and have since then stressed the competitive advantages of leaner production and a more holistic approach to business. Already, in 1995, Sören Gyll set the target for Volvo "to become, and to be considered, one of the world's leading manufacturers in the environmental field by the year 2000." ${ }^{155}$ Leif Johansson claimed that, because of the increased market demand for "environmentally compatible products," companies that could successfully implement environmental programs in their production schemes would gain competitive advantages. ${ }^{156}$ Thus, following the general trend in multinational corporations, greenness moved closer to the core of Volvo's communication. In 1998, the company introduced the S80 model, which was, according to Volvo, the first car in the world to have an environmental declaration of contents. ${ }^{157}$ The S80 was indeed not a small car, however, coming in right below the premium segment. It used 0.94 liters per 10 kilometers, which was considered fuel efficient for a car in the family segment but was 10 percent above the average in Sweden. ${ }^{158}$ Overall, Volvo leaned toward developing larger cars with more powerful engines. Despite the intensive debate on climate change and $\mathrm{CO}_{2}$ emissions, fuel intensity was still not an issue of great concern to the company. The introduction of the cross-country V70 was a clear sign that Volvo would follow the trend toward larger, more powerful cars.

This trend toward larger cars was manifested in the SUV, or Sport Utility Vehicle, and was pronounced primarily among U.S. consumers, who had long preferred big and powerful cars. ${ }^{159}$ Concurrently, U.S. fuel efficiency standards have been less strict compared to, for

153. Williander, “Absorptive Capacity,” 207.

154. Berggren, Magnusson, and Sushandoyo, "Hybrids, Diesel or Both?”; Magnusson and Berggren, "Entering an Era." On the development of the Prius, see Magnusson and Berggren, "Environmental Innovation in Auto Development."

155. Volvo Environmental Data Report, 1995, 5.

156. Volvo Environmental Data Report, 1997, 5.

157. Volvo Annual Report, 1998, 45, SRL.

158. Bilismen i Sverige, 2014, 49.

159. See Black, "Driving Change”; McCarthy, Auto Mania. 
instance, European, Japanese, and Chinese regulation. ${ }^{160}$ The SUV also gained increased consumer attention in Sweden in the late 1990s, and has, since the mid-1980s, been the fastest growing vehicle category in North America. The SUV has been credited as the model segment that has kept the declining North American auto industry profitable, with its 25 percent market share in 2002. ${ }^{161}$ Since the 2010s, SUVs have been the fastest growing market segment within the EU, reaching over 30 percent in $2018 .^{162}$

Volvo's still strong dependency on the American market led them to develop SUV models and to introduce in 1997 an XC (cross-country) edition of its top seller V70, called the V70 XC AWD. In 1997, with the V70 AWD and the XC model, and for the first time since the 1980s, Volvo's sales exceeded one hundred thousand units on the U.S. market alone. ${ }^{163}$ The V70 XC was the first step toward a fully developed SUV. Thus, at the same time as the environment was on the agenda more than ever, with the Kyoto Protocol to control $\mathrm{CO}_{2}$ signed in 1997, Volvo launched cars in the most environmentally contested car segment. ${ }^{164}$ For a brand that has had "environmental care" as a core value for several decades, the company's investments in the SUV model appear to be an oxymoron. Volvo reported that the V70 XC used 10.9 liters per 10 kilometers, ${ }^{165}$ which was not in line with the goal of decreasing fuel intensity 25 percent by 2008. The V70 XC, however, was first and foremost aimed at the American market, which stood for 25 percent of Volvo's total sales in 1998 . $^{166}$

It has indeed been argued that stagnant fuel economy standards, low gasoline prices, a lack of investment by automakers in fuel-efficient technologies, and the popularity of SUVs led of the fuel intensity of passenger cars to increase in the 1990s and 2000s. ${ }^{167}$ Volvo's investment in U.S.-style SUVs was an industry-wide trend, which points to a contradictory development in the entire car industry from the 1990s onward. SUVs became immensely popular among consumers, and virtually all automobile manufacturers followed suit, developing both SUVs and smaller, more fuel-efficient models, including hybrid-electric and full BEVs. As argued by Jones, the phenomenon of attaining the sustainability of one component within the global corporation that coexists with environmentally damaging activities has been a widespread strategy in the corporate world since the 1990s. ${ }^{168}$

Although the automobile industry has paid attention to electric vehicles (EVs) for many decades, the market expansion of EVs is still a very recent phenomenon in Europe, driven by the 2020/2021 standards for $\mathrm{CO}_{2}$. In 2019, only 3.5 percent of new vehicles in Europe and just over 2 percent in the United States were equipped with battery electric or plug-in hybrid drivetrains. ${ }^{169}$ It is not enough to mitigate the climate impact of large vehicles, however. As recently as 2020, the International Energy Agency (IEA) identified SUVs as the most important

160. See An et al., "Passenger Vehicle." Note, however, that the United States was the first country to enact mandatory fuel efficiency standards. The first mandatory EU fuel efficiency standards came into force in 2015.

161. McLean, "SUV Advertising," 59.

162. International Council on Clean Transportation, European Vehicle, 14.

163. Volvo Annual Report, 1997, 4, SRL.

164. McLean, "SUV Advertising," 69-72.

165. Volvo advertisement in Teknikens värld, no. 25, 1997, 23-25.

166. Volvo Annual Report, 1998, 27, SRL.

167. Cook, Automaker Rankings 2018, 5.

168. Jones, Profits, 379.

169. International Energy Agency, Global EV Outlook, 45, 250. 
driver behind the increase in $\mathrm{CO}_{2}$ emissions for the period 2010-2018 after the power sector, but ahead of heavy industries including iron and steel, cement, and aluminum. ${ }^{170}$ The jury is still out on whether an electrification of the automobile fleet will take hold and how encompassing it will be. In 2017, Volvo made headlines when it proclaimed the death of the internal combustion engine, saying that all its new models launched after 2019 would be electric or electric hybrids. However, as the Union of Concerned Scientists stated in 2018, Volvo defined its electrified vehicle as just about anything with an electric motor. This included vehicles utilizing $48 \mathrm{~V}$ stop-start systems that are incapable of being propelled solely by their electric motor at any speed. The Alliance of Automobile Manufacturers, a trade group that represents manufacturers selling 70 percent of all new vehicles in the United States, used an equally loose definition of "electrification."171

\section{Conclusions}

Over the three decades covered by this article, it becomes clear that government regulatory pressure was the primary driver behind Volvo's initiatives to innovate in exhaust emission control technologies. Volvo has actively and, in the case of the U.S. CAA amendments, proactively complied with government regulations, but never adopted a strategy to go beyond legal compliance for the sake of the environment. At the same time Volvo did successfully communicate its achievements to enhance the value of its brand as "green." Premium and green branding emerged as complementary assets for Volvo in the 1990s, although the company lacked the initiative and capability to break with old trajectories in order to address climate change.

As this article has demonstrated, Volvo's early dependency on the U.S. market drove the company to invent and introduce the three-way catalytic converter (TWC) on the California market in the 1970s. Coupled with the decision to adopt "environmental care" as one of its core values in 1972, Volvo emerged as a pioneering company in addressing environmental issues. The 1970s thus created a legacy whereby the Volvo brand came to be associated with responsibility for the environment as well as safety, with the company's CEO, Gyllenhammar, acting as an activist by helping to raise the company's environmental profile. The question is, what factors drove Volvo to lose its leading position in controlling vehicle emissions? At least three interrelated key factors can be identified that limited or affected the greening of Volvo after the 1970s.

The first complicating factor was Volvo's market position. The fact that it was a small car producer made the company a niche manufacturer in the Western world, serving the segment of buyers valuing safety and comfort. After the 1970s, safety remained Volvo's competitive strategy, while the company moved further into premium products in the 1990s. As Volvo's "safety" strategy brought more weight to the car-such as robust constructions-it also meant a trade-off in terms of fuel consumption. At the same time, this was nothing that the customers in Volvo's market segment worried about. The fact that the company aimed for the premium

170. Cozzi, "Growing Preference."

171. Cook, Automaker Rankings 2018, 27. 
segment and launched its first SUV in 1997, the same year as the Kyoto Protocol was signed, highlights contradictions in the greening of capitalism. It was an industry-wide trend, whereby larger automobile firms developed both smaller and "clean" fuel-efficient car models alongside SUVs.

Second, the complexities of trade relations and national interests in constructing a European governance system of automobile emissions delayed action in Europe. In practice, automobile companies like Volvo were bounded to produce cars that were more polluting for the European market than for the U.S. market in the 1980s. Apart from the deterrable, additional costs of TWC systems when regulatory standards do not require advanced emission control, unleaded gasoline is the case in point. Volvo, or any other brand, could not produce cars equipped with TWC systems for the European market until unleaded gasoline was widely provided. It was not until 1989 that the EEC/EU countries required the availability of unleaded gasoline, something that the U.S. EPA had already required in the early 1970s.

Third, our study demonstrates that the barriers Volvo faced in addressing the evolving environmental issue largely existed outside its firm boundaries. There is little to suggest that Volvo's loss of leadership on the environmental issue signifies any particular vice or flaw within the company itself. As has been stressed in recent business history studies by, for example, Geoffrey Jones and Adam Rome, the market realities have often worked against radical green initiatives in large, established corporations. ${ }^{172}$ Our study of Volvo showcases how an early green pioneer in the 1970s never established an orientation to address climate change, the most critical problem of our time. We have identified a lack of regulatory pressure on the company's primary markets, along with a lack of financial strength, as important reasons why Volvo did not develop new and less $\mathrm{CO}_{2}$-intensive technologies.

However, studying the case of Volvo does not catch all the factors that have driven or prevented the automobile industry from transforming toward lower exhaust (tailpipe) emissions, including climate gases. This study has only scratched the tip of the iceberg, and similar historical case studies of other automakers are needed to enable systematic comparisons. For example, this study has only touched upon some of the complexities associated with the creation of harmonized vehicle emission standards and how they forced firms to take action or put obstacles in place to prevent them from doing so, depending on their market position. Complexities regarding businesses' impact and lobbying on the political process of vehicle emission standards in the United States and the EEC/EU are issues that were not covered in this study. The extent to which automobile firms have manipulated information on emissions and fuel efficiency performance, and the size of the trade-offs resulting from counteracting technical regulations on safety and emission control, are examples of other issues that beg for more research.

Finally, as this article indicates, Volvo chose to stay safe before going green, and the company played it safe in a dual sense. The first sense of "safe" was related to technical aspects of vehicle safety and "safety" branding, whereas the second sense can be called safe

172. Jones, Profits; Rome, "DuPont." 
business decisions, involving sticking to conventional petroleum-based technologies, protecting its market position, and going premium after the 1990s.

ANN-KRISTIN BERgQUIST is associate professor in economic history at Umeå University. Her research is focused on business and economic history and environmental sustainability. She has published a number of book chapters and articles in Business History Review, Business History, Journal of Cleaner Production, Ecological Economics, and a number of other journals. E-mail: ann-kristin.bergquist@umu.se

Mattias Näsman is a PhD candiate in economic history at Umeå University. His thesis concerns the political economy of car emission regulation in Sweden and Europe. E-mail: mattias. nasman@umu.se

\section{Acknowledgements}

The authors want to thank the three anonymous reviewers for helpful comments that improved the manuscript significantly. We would also like to thank William Childs for helpful comments at an early stage of this manuscript. Financial support from the Jan Wallander and Tom Hedelius Foundation is gratefully acknowledged.

Bibliography and Works Cited

\section{Books}

Boehmer-Christiansen, Sonja, and Helmut Weidner. The Politics of Reducing Vehicle Emissions in Britain and Germany. London: Pinter, 1995.

Egan, Michelle. Constructing a European Market: Standards, Regulation, and Governance. Oxford: Oxford University Press, 2001.

Elsässer, Björn. Svensk bilindustri: en framgångshistoria. Stockholm: Studieförbundet Näringsliv och Samhälle, 1995.

Engfeldt, Lars-Göran. From Stockholm to Johannesburg and Beyond. Stockholm: The Government Offices of Sweden, 2009.

Geels, Frank W., René Kemp, Geoff Dudley, and Glenn Lyons. Automobility in Transition? A SocioTechnical Analysis of Sustainable Transport. New York: Routledge, 2012.

Gyllenhammar, Pehr G. Jag tror på Sverige. Stockholm: Askild och Kärnekull, 1973.

Haventon, Peter. Volvo's Value Lasts: A History of Volvo Car Corporation 1927-2008. Gothenburg, SE: Volvo Car Corporation, Public Affairs, 2008.

Hökerberg, Jan. Spelet om Volvo. Stockholm: Ekerlinds Förlag, 2000.

Jones, Daniel T. Maturity and Crisis in the European Car Industry: Structural Change and Public Policy. Sussex, UK: Sussex European Research Centre, 1981.

Jones, Geoffrey. Profits and Sustainability. A History of Green Entrepreneurship. Oxford: Oxford University Press, 2017.

Jönsson, Sten, and Mikael Wickelgren, eds. Volvo i våra hjärtan—hur skall det gå? En närdiskussion om "nationalklenoden" Volvo. Malmö, SE: Liber AB, 2011. 
Krier, James E., and Edmund Ursin. Pollution and Policy: A Case Essay on California and Federal Experience with Motor Vehicle Air Pollution 1940-1975. Berkeley: University of California Press, 1977.

Lundqvist, Lennart J. The Hare and the Tortoise: Clean Air Policies in the US and Sweden. Ann Arbor: University of Michigan Press, 1980.

McCarthy, Tom. Auto Mania: Cars, Consumers, and the Environment. London: Yale University Press, 2007.

McLaughlin, Andrew M., and William A. Maloney. The European Automobile Industry: Multi-level Governance, Policy and Politics. London: Routledge, 1999.

Mondt, Robert J. Cleaner Cars: The History and Technology of Emission Control since the 1960s. Warrendale, PA: Society of Automotive Engineers, 2000.

Olsson, Christer, and Henrik Moberg. Volvo. Gothenburg. Sweden. St. Gallen, CH: Norden Publishing House, 1995.

Rome, Adam. The Genius of Earth Day: How a 1970 Teach-In Unexpectedly Made the First Green Generation. New York: Hill and Wang, 2013.

Vogel, David. The Politics of Precaution: Regulating Health, Safety, and Environmental Risks in Europe and the United States. Princeton: Princeton University Press, 2012.

- Trading Up: Consumer and Environmental Regulation in a Global Economy. Cambridge, MA: Harvard University Press, 1995.

Wurzel, Rüdiger K. W. Environmental Policy-Making in Britain and the European Union: The Europeanisation of Air and Water Pollution Control. Manchester, UK: Manchester University Press.

\section{Articles and Chapters in Books}

Aghion, Philippe, Antoine Dechezleprêtre, David Hémous, Ralf Martin, and John van Reenen. "Carbon Taxes, Path Dependency, and Directed Technical Change: Evidence from the Auto Industry." Journal of Political Economy 124, no. 1 (2016): 1-51.

Bauner, David. "International Private and Public Reinforcing Dependencies for the Innovation of Automotive Emission Control Systems in Japan and USA." Transportation Research Part A: Policy and Practice 45, no. 5 (2011): 375-388.

Bento, Nuno. "Is Carbon Lock-In Blocking Investments in the Hydrogen Economy? A Survey of Actors' Strategies." Energy Policy 38, no. 11 (2010): 7189-7199.

Berggren, Christian. "Volvo: A Comeback or Farewell?” In One Best Way? Trajectories and Industrial Models of the World's Automobile Producers, edited by Michel Freyssenet, Andrew Mair, Kochi Shimizu, and Giuseppe Volpato, 418-439. Oxford: Oxford University Press, 1998.

Berggren, Christian, and Thomas Magnusson. "Reducing Automotive Emissions-The Potentials of Combustion Engine Technologies and the Power of Policy." Energy Policy 41 (February 2012): 636-643.

Berggren, Christian, Thomas Magnusson, and Dedy Sushandoyo. "Hybrids, Diesel or Both? The Forgotten Technological Competition for Sustainable Solutions in the Global Automotive Industry." International Journal of Automotive Technology and Management 9, no. 2 (2009): 148-173.

Bergquist, Ann-Kristin. "Business and Sustainability." In The Routledge Companion to the Makers of Global Business, edited by Teresa da Silva Lopez, Christina Lubinski, and Heidi J. S. Tworek, 546-563. London: Routledge, 2019.

Bergquist, Ann-Kristin. "Dilemmas of Going Green: Environmental Strategies in the Swedish Mining Company Boliden 1960-2000." In Green Capitalism? Business and the Environment in the Twentieth Century, edited by Hartmut Berghoff and Adam Rome, 149-171. Philadelphia: Pennsylvania University Press, 2017. 
. "Renewing Business History in the Era of the Anthropocene." Business History Review 93, no. 1 (2019): 3-24.

Bergquist, Ann-Kristin, and Kristina Söderholm. "Green Innovation System in Swedish Industry.” Business History Review 84, no. 4 (2011): 677-698.

Bergquist, Ann-Kristin, John Ehrenfeld, Shawn Cole, Andrew A. King, and Auden Schendler. "Roadblocks to Environmental Sustainability: Past Roads and Future Prospects." Business History Review 93, no. 1 (2019): 127-148.

Black, Brian. "Driving Change: The Winding Road to Greener Automobiles.” In Green Capitalism? Business and the Environment in the Twentieth Century, edited by Hartmut Berghoff and Adam Rome, 231-250. Philadelphia: University of Pennsylvania Press, 2017.

Briggs, Max, Jeremy Webb, and Clevo Wilson. "Automotive Modal Lock-in: The Role of Path-Dependency and Large Socio-economic Regimes in Market Failure." Economic Analysis and Policy 45 (March 2015): 58-68.

Bruner, Robert, and Robert Spekman. "The Dark Side of Alliances: Lessons from Volvo-Renault." European Management Journal 16, no. 2 (1998): 136-150.

Calabrese, Giuseppe. "Innovative Design and Sustainable Development in the Automotive Industry." In The Greening of the Automotive Industry, edited by Giuseppe Calabrese, 13-31. Basingstoke, UK: Palgrave Macmillan, 2012.

Callon, Michel. "Society in the Making: The Study of Technology as a Tool for Sociological Analysis." In The Social Construction of Technological Systems: New Directions in Sociology and History of Technology, anniversary edition, edited by Wiebe Bijker, Thomas P. Hughes, and Trevor Pinch, 77-98. Cambridge, MA: MIT Press, 2012.

Coen, David. "Environmental and Business Lobbying Alliances in Europe: Learning from Washington?" In The Business of Global Environmental Governance, edited by David L. Levy and Peter J. Newell, 197-222. Cambridge, MA: MIT Press, 2005.

Collantes, Gustavo, and Daniel Sperling. "The Origin of California’s Zero Emission Vehicle Mandate." Transportation Research Part A: Policy and Practice 42, no. 10 (2008): 1302-1313.

Cowles, Maria Green. "Setting the Agenda for a New Europe: the ERT and EC 1992." Journal of Common Market Studies 33, no. 4 (1995): 501-526.

Cowles, Green Maria. "Large Firms and the Transformation of EU Business Associations: A Historical Perspective." In The Effectiveness of EU Business Associations, edited by Justin Greenwood, 64-78. New York: Palgrave Macmillan, 2002.

Dijk, Marc, Jorrit Nijhuis, and Reinhard Madlener. "Consumer Attitudes towards Alternative Vehicles." In The Greening of the Automotive Industry, edited by Giuseppe Calabrese, 286-303. Basingstoke, UK: Palgrave Macmillan, 2012.

Eisler, Matthew N. "Public Policy, Industrial Innovation, and the Zero-Emission Vehicle." Business History Review 94, no. 4 (Winter 2020): 779-802.

Esty, Daniel C., and Damien Geradin. "Market Access, Competitiveness, and Harmonization: Environmental Protection in Regional Trade Agreements." Harvard Environmental Law Review 21, no. 2 (1997): 265-336.

Fredrickson, Leif. "The Rise and Fall of an Ecostar: Green Technology Innovation and Marketing as Regulatory Obstruction." In Green Capitalism? Business and the Environment in the Twentieth Century, edited by Hartmut Berghoff and Adam Rome, 132-148. Philadelphia: University of Pennsylvania Press, 2017.

Gerard, David, and Lester B. Lave. "Implementing Technology-Forcing Policies: The 1970 Clean Air Act Amendments and the Introduction of Advanced Automotive Emissions Controls in the United States." Technological Forecasting and Social Change 72, no. 7 (2005): 761-778. 
Hooftman, Nils, Maarten Messagie, Joeri Van Mierlo, and Thierry Coosemans. "A Review of the European Passenger Car Regulations—Real Driving Emissions vs Local Air Quality.” Renewable and Sustainable Energy Reviews 86 (April 2018): 1-21.

Høyer, Karl Georg. "The History of Alternative Fuels in Transportation: The Case of Electric and Hybrid Cars." Utilities Policy 16, no. 2 (2008): 63-71.

Johanson, Jan, and Jan-Erik Vahlne. "The Internationalization Process of the Firm-A Model of Knowledge Development and Increasing Foreign Market Commitments." Journal of International Business Studies 8, no. 1 (1977): 23-32.

Kantz, Orley. "Volvo's Holistic Approach to Environmental Strategy." Corporate Environmental Strategy 7, no. 2 (2000): 156-169.

Klier, Thomas, and Joshua Linn. "The VW Scandal and Evolving Emissions Regulations." Chicago Fed Letter, no. 357 (2016): 1-4.

Köhler, Ingo. "Overcoming Stagnation: Product Policy and Marketing in the German Automobile Industry of the 1970s." Business History Review 84, no. 1 (Spring 2010): 53-78.

—. "'Small Car Blues' Die Produktpolitik US-amerikanischer und deutscher Automobilhersteller unter dem Einfluss umweltpolitischer Vorgaben, 1960-1980.” Jahrbuch für Wirtschaftsgeschichte 51, no. 1 (2010): 107-136.

Lee, Jaegul, Francisco M. Veloso, David A. Hounshell, and Edward S. Rubin. "Forcing Technological Change: A Case of Automobile Emissions Control Technology Development in the US." Technovation 30, no. 4 (2010): 249-264.

Magnusson, Thomas, and Christian Berggren. "Entering an Era of Ferment-Radical vs Incrementalist Strategies in Automotive Power Train Development." Technology Analysis and Strategic Management 23, no. 3 (2011): 313-330.

—. "Environmental Innovation in Auto Development-Managing Technological Uncertainty within Strict Time Limits.” International Journal of Vehicle Design 26, no. 2/3 (2001): 101-115.

Mårald, Erland. "Methanol as Future Fuel: Efforts to Develop Alternative Fuels in Sweden after the Oil Crisis." History and Technology: An International Journal 26, no. 4 (2010): 335-357.

McLean, Fiona. "SUV Advertising: Constructing Identities and Practices." In Car Troubles: Critical Studies of Automobility and Auto-Mobility, edited by Jim Conley and Arlene Tigar McLaren, 59-78. Farnham, UK: Ashgate Publishing, 2009.

Moguen-Toursel, Marine. "Strategies of European Automobile Manufacturers Facing Community Environmental Standards." Business and Economic History On-Line 1, (2003): 1-28.

—. "Vers une co-production des standards automobiles environnementaux au plan communautaire?" In La Responsabilité Sociale de l'Entreprise: Nouvelle régulation du capitalisme?, edited by Frédéric Chavy, Nicolas Postel, Richard Sobel, and Didier Cazal, 259-270. Villeneuve, FR: Presses universitaires du Septentrion Collection, 2011.

Needleman, Herbert, and David Gee. "Lead in Petrol 'Makes the Mind Give Way.'” In Late Lessons from Early Warnings: Science, Precaution, Innovation, 46-75. EEA Report No. 1/2013. Luxembourg: Publications Office of the European Union, 2013.

Nichols, Roberta J. "The Methanol Story: A Sustainable Fuel for the Future.” Journal of Scientific and Industrial Research 62, no. 1-2 (2003): 97-105.

Norland, S. A. "Tillgången på olja och framtida drivsystem.” In Motorer för vägfordon: Finns det några alternative när oljepriserna stiger? : föredrag och diskussionsinlägg från seminariet den 8 juni 1977. 19-32. Stockholm, Transportforskningskommissionen TFK, 1977.

Orsato, Renato J., and Peter A. Wells. "The Automobile Industry and Sustainability." Journal of Cleaner Production 15, no. 11-12 (2007): 989-993. 
Perkins, Richard, and Eric Neumayer. "Does the 'California Effect' Operate across Borders? Trading- and Investing-Up in Automobile Emission Standards.” Journal of European Public Policy 19, no. 2 (2012): 217-237.

Ramírez-Pérez, Sigfrido. "International Business Networks Propagating EC Industrial Policy: The Role of the Committee of Common Market Automobile Constructors.” In The History of the European Union: Origins of a Trans- and Supranational Polity 1950-1972, edited by Wolfram Kaiser, Birgitte Leucht, and Morten Rasmussen, 74-92. New York: Routledge, 2009.

—. "Multinational Corporations and European Integration: The Case of the Automobile Industry, 1959-1965." Journal of European Integration 22, no. 2 (2016): 329-354.

Rome, Adam. "DuPont and the Limits of Corporate Environmentalism." Harvard Business Review 93, no. 1 (2019): 75-99.

Rosegger, Gerhard. "Interfirm Cooperation and Structural Change in the European Automobile Industry." Review of Industrial Organization 11, no. 5 (1996): 699-720.

Rothenberg, Sandra, and James Maxwell. "Extending the Umbrella of Social Concern: Volvo's Strategic Approach to Environmental Management.” Corporate Environmental Strategy 3, no. 2 (1995): 5-16.

Rothenberg, Sandra, James Maxwell, and Alfred Marcus. "Issues in the Implementation of Proactive Environmental Strategies.” Business Strategy and the Environment 1, no. 4 (1992): 1-12.

Tengblad, Stefan. "Visionen om det samhällsnyttiga företaget." In Volvo i våra hjärtan—hur skall det gå? En närdiskussion om 'nationalklenoden' Volvo, edited by Sten Jönsson and Mikael Wickelgren, 63-85. Malmö, SE: Liber AB, 2011.

Unruh, Gregory C. “Escaping Carbon Lock-In.” Energy Policy 30, no. 4 (2002): 317-325.

—. "Understanding Carbon Lock-In." Energy Policy 28, no. 12 (2000): 817-830.

Walsh, Michel P. “Automobile Emissions.” In The Reality of Precaution: Comparing Risk Regulation in the United States and Europe, edited by Jonathan B. Wiener, Michael D. Rogers, James K. Hammitt, and Peter H. Sand, 142-158. Washington, DC: RFF Press, 2011.

Wells, Peter, Paul Nieuwenhuis, and Renato J. Orsato. "The Nature and Causes of Inertia in the Automotive Industry." In Automobility in Transition? A Socio-Technical Analysis of Sustainable Transport, edited by Frank W. Geels, René Kemp, Geoff Dudley, and Glenn Lyons, 123-139. New York: Routledge, 2012.

Wickelgren, Mikael. "En skiss över Volvos historia.” In Volvo i våra hjärtan—hur skall det gå? En närdiskussion om "nationalklenoden" Volvo, edited by Sten Jönsson and Mikael Wickelgren, 30-62. Malmö, SE: Liber AB, 2011.

—. "Varumärket Volvo." In Volvo i våra hjärtan-hur skall det gå? En närdiskussion om "nationalklenoden" Volvo, edited by Sten Jönsson and Mikael Wickelgren, 86-114. Malmö, SE: Liber $\mathrm{AB}, 2011$.

Wilkins, Mira. "Multinational Automobile Enterprises and Regulation: An Historical Overview." In Government, Technology and the Future of the Automobile, edited by Douglas H. Ginsburg and William J. Abernathy, 221-258. New York: McGraw-Hill Book Company, 1978.

Williander, Mats. “Absorptive Capacity and Interpretation System's Impact when 'Going Green': An Empirical Study of Ford, Volvo Cars and Toyota." Business Strategy and the Environment 16, no. 3 (2007): 202-213.

\section{Governmental Documents, Reports, and Internet Sources}

An, Feng, Deborah Gordon, Hui He, Drew Kodjak, and Daniel Rutherford. Passenger Vehicle Greenhouse Gas and Fuel Economy Standards: A Global Update. Washington, DC: International Council of Clean Transportation, 2007. 
Cook, Dave. Automaker Rankings 2018. The Environmental Performance of Car Companies. Cambridge, MA: Union of Concerned Scientists, 2018. https://www.ucsusa.org/sites/default/files/attach/2018/ 06/cv-automaker-rankings-2018-report.pdf.

Cozzi, Laura. "Growing Preference for SUVs Challenges Emissions Reductions in Passenger Car Market." International Energy Agency. Accessed January 13, 2020. https://www.iea.org/commentaries/grow ing-preference-for-suvs-challenges-emissions-reductions-in-passenger-car-market.

European Environment Agency. Monitoring CO2 Emissions from Passenger Cars and Vans in 2013. EEA Technical Report, no. 19. Luxembourg: Publications Office of the European Union, 2014.

The Guardian. “All Volvo Cars to Be Electric or Hybrid from 2019.” Accessed November 19, 2019. https:// www.theguardian.com/business/2017/jul/05/volvo-cars-electric-hybrid-2019.

International Council on Clean Transportation. European Vehicle Market Statistics. Pocketbook 2019/20. Berlin: International Council on Clean Transportation Europe, 2019. https://theicct.org/sites/default/ files/publications/European_vehicle_market_statistics_20192020_20191216.pdf.

International Energy Agency. Global EV Outlook 2020: Entering the Decade of Electric Drive? Paris: IEA Publications, 2019.

Lönnroth, Måns. The Organisation of Environmental Policy in Sweden: A Historical Perspective. Swedish Environmental Protection Agency, Report 6404. Bromma, SE: Naturvardsverket, 2010.

Nesbit, Martin, Malcolm Fergusson, Alejandro Colsa, Jana Ohlendorf, Christina Hayes, Kamila Paquel, Jean-Pierre Schweitzer. Comparative Study on the Differences between the EU and US Legislation on Emissions in the Automotive Sector. Brussels: EU Directorate General for Internal Policies, Policy Department A: Economic and Scientific Policy, 2016.

Swedish Ministry of Agriculture. Bilarna och luftföroreningarna: lägesrapport från bilavgaskommittén. SOU 1979:34, Stockholm.

Swedish Ministry of Transportation. Avgaser från bensindrivna bilar-utredning med förslag till åtgärder. Ds K 1968:2, Stockholm.

—. Luftföroreningar genom bilavgaser—slutbetänkande. Ds K 1971:1, Stockholm.

United States Environmental Protection Agency. Automobile Emission Control-The Development Status, Trends and Outlook as of December 1976. Office of Mobile Source Air Pollution Control, 1977, Washington D.C.

- Automobile Emission Control-The State of the Art as of December 1972. Office of Mobile Source Air Pollution Control, 1973, Washington D.C.

Volvo Car Group. Annual Report 2019. Accessed March 5989, 2020. https://investors.volvocars.com/ annualreport2019/assets/pdf/VCG_AR_ENG_20200326.pdf.

\section{Dissertations and Working Papers}

Arp, Henning. Multiple Actors and Arenas: European Community Regulation in a Polycentric System A Case Study on Car Emission Policy. Diss. Florence: European University Institute.

Berggren, Christian. Det nya bilarbetet - Konkurrensen mellan olika produktionskoncept i svensk bilindustri 1970-1990. Diss. Lund: Studentlitteratur, 1990.

Bergquist, Ann-Kristin and Kristina Söderholm. "Business and Green Knowledge Production in Sweden 1960s-1980s”. Harvard Business School Working Paper. No. 18-034 (2017).

Jagrén, Lars. Företagens Tillväxt i Historiskt Perspektiv, IUI, Working Paper No. 195 (1986).

Collantes, Gustavo. The California Zero-Emission Vehicle Mandate: A Study of the Policy Process, 19902004. Diss. University of California, Davis, 2006.

Glimstedt, Henrik. Mellan teknik och samhälle. Diss. Gothenburg: University of Gothenburg, 1993. 
Lundin, Per. Bilsamhället: ideologi, expertis och regelskapande i efterkrigstidens Sverige. Diss. Stockholm: Royal Institute of Technology, 2008.

Palmås, Karl. ReVolvolutions: Innovation, Politics and the Swedish Brand. Diss. London: London School of Economics, 2005.

\section{Magazines, Corporate Reports, Statistical Abstracts}

\section{Bilismen i Sverige.}

Daily Nation, "Motor Industrialists to Meet in Nairobi to Discuss Pollution", Nov 15, 1973, 3.

Mobility and the environment. The Volvo view (downloaded from the web in 2015, but not accessible now).

Ratten: Volvos tidning.

Teknikens värld.

Time International Edition.

Environmental Reports (downloaded from the Volvo Corporate Group's website in 2015, but not accessible now).

World Motor Vehicle Data.

\section{Archival Sources}

Environmental Science and Policy Archives, Harvard Library (HL), Boston, MA

Swedish Code of Statutes

Swedish National Archives (SNA), Stockholm, SE

Swedish Parliamentary Documents, Government Bills

Swedish Royal Library (SRL), Stockholm, SE

Cite this article: Bergquist, Ann-Kristin, and Mattias Näsman. "Safe before Green! The Greening of Volvo Cars in the 1970s-1990s.” Enterprise \& Society 24, no. 1 (2023): 59-89. 